\title{
IDENTIFICATION AND CHANGES OF SUBSIDENCE BASINS CAUSED BY COAL MINING ACTIVITY IN UPPER SILESIA USING SATELLITE INTERFEROMETRIC DATA
}

\author{
Maria Przyłucka $^{(1)}$, Marek Graniczny $^{(1)}$, Zbigniew Kowalski $^{(1)}$ \\ (1) Polish Geological Institute - National Research Institute, Rakowiecka Street no. 4, 00-975 Warsaw, Poland, \\ Email: maria.przylucka@pgi.gov.pl, marek.graniczny@pgi.gov.pl, zbigniew.kowalski@pgi.gov.pl
}

\begin{abstract}
The mining exploitation of hard coal in Upper Silesia Coal Basin, USCB, (Southern Poland) has been conducted since XIX century and continues to the present days. The most common operating system in USCB is longwall coal mining. Subsidence can reach up to $70 \%$ of the excavated coal layer, which represents a 0.75-2.0 m displacement for typical $2.5 \mathrm{~m}$ layer. In this study DInSAR technology was used to identification and monitoring subsidence basins caused by underground coal mining activities. Two sets of differential interferograms were used for comparison and analysis: ALOS - PALSAR, period 22/02/2007 27/05/2008 and TerraSAR-X, period 05/07/201121/06/2012. The analysis of the ALOS - PALSAR data enabled identification of 51 subsidence basins, whereas newer TSX satellite data allowed the identification of 31 active sites. In several cases it was also possible to determine direction and development of subsidence movement which correlated most probably with movement of underground mining fronts.
\end{abstract}

\section{INTRODUCTION}

Satellite Radar Interferometry is a technique used for over 20 years to detect changes in Earth's topography. In the 90's, the first attempts to use Radar Differential SAR interferometry (DInSAR) to study movements in mining induced areas in Poland has been carried out [1]. In the beginning, for generation of interferograms from ERS-1, C-band satellite was used. Results show that Cband wavelength interferometry is not able correctly retrieve the deformation rates for localized subsidence cones with a subsidence larger than $10 \mathrm{~cm}$ [2]. Launch Japanese L-band satellites J-ERS-1 (1992) and ALOSPALSAR (2006), enabled detect areas with high displacement rates. Additionally at the longer L-band wavelength the decorrelation of the signal in vegetation is reduced. For 46 day and 92 day intervals the interferometric phase was found to be interpretable even for forested areas [3]. Another significant step in the development of satellite interferometry was launch of TerraSAR-X (TSX) in 2007. The high spatial resolution of TSX sensor and 11-day repeat interval enable to measure high deformation rates. However, one disadvantage of using TerraSAR-X data is related to the loss of coherence in rural and forested areas [4]. This paper showing pros and cons of L-band and X-band sensors in detection mining induced subsidence basins.

\section{STUDY AREA}

The Upper Silesian Coal Basin (USCB) is located around the town of Katowice in the North, Cracow (East) and the Czech border (South). The USCB covers an area of about $7,400 \mathrm{~km}^{2}$ in southern Poland and in the Ostrava-Karvina region in the Czech Republic. The Polish part is about $5,800 \mathrm{~km}^{2}$. It is the most important coal basin of Poland and also one of the largest in Europe. Up to $30 \%$ of the deposit is explored by recent mining operations. The reserve deposits cover $23 \%$ and the perspective areas cover about $27 \%$ of the whole area. At the moment over $80 \%$ of coal deposits in Poland occur in this area.

The USCB was formed as a foredeep of the MoravoSilesian fold zone. It is a deep molasses basin of different origin. The layers of Namurian age was deposited in a paralic environment and the upper part from late Namurian to Westphalian is of continental origin. The coal-bearing formations were subjected to erosion and denudation after the Variscan uplift. In the southern part of the basin, the coals are overlain by Miocene interbedded clay and sand of marine origin, and in the northern part by Permian-Jurassic layers. In the central part the Pennsylvanian strata are covered only by Quaternary sediments [5]. The basin comprises a thick sequence of Upper Carboniferous sediments, up to $8,500 \mathrm{~m}$. The rocks of that sequence include four lithostratigraphic units - the Paralic Series, Upper Silesian Sandstone Series, Siltstone Series and Cracow Sandstone Series. They represent Namurian and Westphalian ages. The upper part contains 60 coal seams and the lower part of the sequence contains 250 coal seams. The thickness of the seams can be up to $6-7 \mathrm{~m}$. The mining operations in this basin are complicated because of the large scale faulting and folding caused by the high tectonics. Igneous intrusions of the Permian, Triassic and Miocene age influenced the coal rank. The coal is primarily high volatile bituminous, with low ash and sulphur contents.

The mining exploitation of hard coal in Upper Silesia Coal Basin (USCB) - Southern Poland has been conducted since XIX century and continues to the 
present days. During the period 1945-1979, on average, 200 million tonnes of hard coal were exploited yearly. From the late $80 \mathrm{~s}$, a steady decrease reached 79 million tonnes in 2012. Urban growth was parallel to mining industry development, reaching 37 towns with almost 3 million inhabitants nowadays. The most common operating system in USCB is longwall coal mining. Usually, the excavated coal layer is $2.5 \mathrm{~m}$ thick, 250 to $400 \mathrm{~m}$ long, and about $680 \mathrm{~m}$ deep. According to [6] subsidence can reach up to $70 \%$ of the excavated coal layer, which represents a $0.75-2.0 \mathrm{~m}$ displacement for every layer. Different methods of monitoring subsidence of the earth surface were applied in this area, starting from analysis of topographic maps compiled in different period of time, precise leveling, laser scanning and GPS measurements.

In this study DInSAR technique was used for subsidence basin development analysis over a part of Upper Silesian Coal Basin (Fig. 1, red square). The area of interest covers $963 \mathrm{sq} \mathrm{km}$ and is located in very active mining region, where 15 coal mines are currently operating underground.

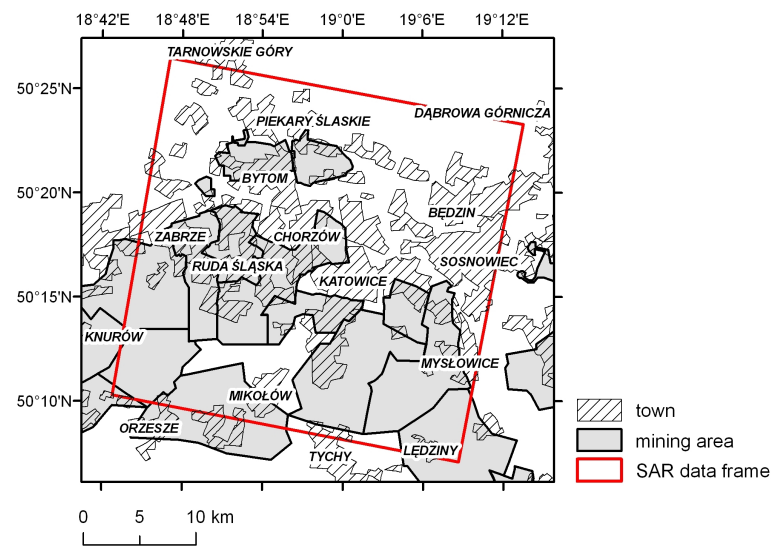

Figure 1. Geographical setting of the study area with TerraSAR-X data frame and the boundaries of coal mining areas in Upper Silesia Coal Basin [7]

\section{SAR DATA CHARACTERISTIC}

Two sets of differential interferograms were used for comparison and analysis: ALOS - PALSAR, period $22 / 02 / 2007$ - 27/05/2008 and TerraSAR-X, period 05/07/2011- 21/06/2012. The detail characteristic of the datasets is presented in Tab. 1 .
Table 1. Summary of the data sets

\begin{tabular}{|c|c|c|}
\hline No. & 1 & 2 \\
\hline Satellite & ALOS & TerraSAR-X \\
\hline Geometry/Track & n/a & Desc/T108 \\
\hline Band (Wavelength) & L $(23.6 \mathrm{~cm})$ & $\mathrm{X}(3.1 \mathrm{~cm})$ \\
\hline No. of scenes & 6 & 30 \\
\hline No. of interferograms & 30 & 28 \\
\hline \multirow{2}{*}{ Time period } & $22 / 02 / 2007-$ & $05 / 07 / 2011-$ \\
& $27 / 05 / 2008$ & $21 / 06 / 2012$ \\
\hline
\end{tabular}

The datasets significantly differ from each other. Processing of ALOS-PALSAR scenes provided five differential interferogrmas with time spans 46, 92 or 138 days, covering the period of 15 months. In contrary from TerraSAR-X scenes twenty eight 11-days interferograms were acquired for period of one year. On both types of interferograms subsidence is presented in a form of fringes, but in different colour bar and with different range as a result of various wavelength and time span. On L-band 46-day interferogram up to $30 \mathrm{~cm}$ displacement was captured, whereas on X-band 11-day interferogram up to $7.5 \mathrm{~cm}$. Moreover ALOS interferograms were unwrapped and TSX were not, which makes interpretation of exact subsidence values more difficult. The example of subsidence basin visible at the interferograms is presented on Fig. 2a, b and c for ALOS dataset and Fig. 2f, $g$ and $h$ for TSX dataset. Despite these differences, on both datasets it was possible to successfully identified boundaries of the subsidence basin visible in particular interferogram time span (black lines on Fig. 2 a-c and f-h).

\section{METHODOLOGY}

The analysis of development of subsidence basin were preformed separately for period 22/02/2007-27/05/2008 and $05 /-7 / 2011-21 / 06 / 2012$. For each of the 5 ALOS and 28 TSX interferograms the boundaries of the basins were manually digitized (in Fig. 2a-c and f-h is presented an example from Mysłowice area). In the next step the direction and development of subsidence movement was analysed by the comparison of the shape and place of indentified boundaries in relation to all the other lines from all other dates. By displaying the boundaries chronologically (in Fig. $2 \mathrm{~d}$ and $\mathrm{i}$ is presented an example from three selected inteferograms) the direction of the movement was defined and visualized by the arrow or dot (for the basins were no movement was seen). Furthermore all the shapes of the basin were aggregated and resulting subsidence basin areas for both monitoring period were defined (Fig 2e and $\mathrm{j}$ ). 

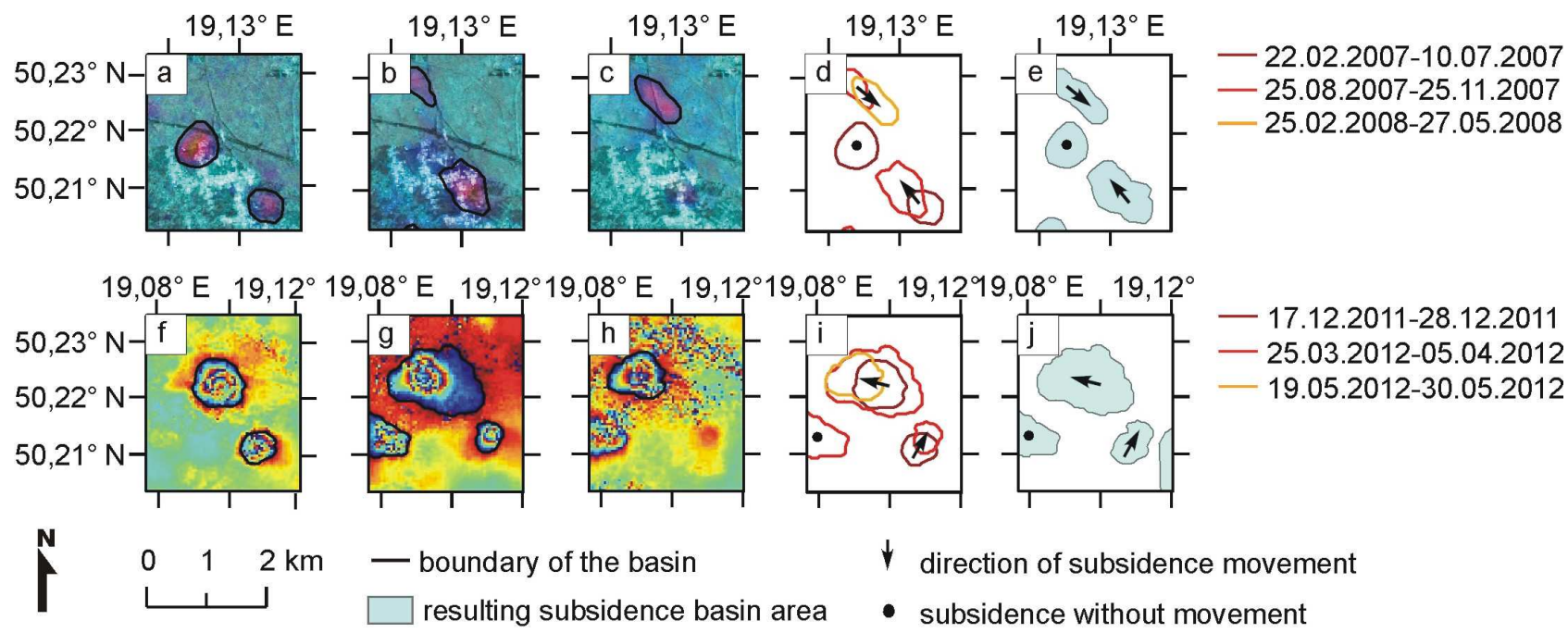

\section{$\downarrow$ direction of subsidence movement \\ - subsidence without movement}

Figure 2. Mystowice area. An example of the performed methodology in order to obtain subsidence basin areas and the direction of the ground displacement movement. a-c. ALOS-PALSAR interferograms time span: 22.02.2007-10.07.2007, 25.08.2007-25.11.2007, 25.02.2008-27.05.2008. d. Digitized boundaries of the basin presented in a different colours depending on the interferogram date and the defined direction of the displacement movement. e. Resulting subsidence basin areas for monitoring period 22.02.2007-27.05.2008. $f$-h. TerraSAR-X interferograms time span 17.12.201128.12.2011, 25.03.2012-05.04.2012, 19.05.2012-30.05.2012. i. Digitized boundaries of the basin presented in a different colours depending on the interferogram date and the defined direction of the displacement movement. j. Resulting subsidence basin areas for monitoring period 05.07.2011-21.06.2012.

\section{RESULTS AND DISCUSSION}

The analysis has covered central part of USCB between Piekary Śląskie (N), Zabrze (W), Tychy (S) and Mysłowice (E). The analysis of the ALOS - PALSAR data enabled identification of 51 subsidence basins (Fig. 3), whereas newer TSX satellite data allowed the identification of 31 active sites (Fig. 4). Most of the subsidence basins were located within mining area, however in some cases they exceeded boundaries of mining areas. In several cases it was also possible to determine direction and development of subsidence movement which correlated most probably with movement of underground mining fronts. Identified subsidence basins are arranged in about longitudinal zone in central part of the Upper Silesian Basin almost continuously from Zabrze to Mysłowice. In addition, there is one other zones: in the north, latitudinal between Piekary Śląskie and Bytom.

The comparison of subsidence basin was performed between years 2008 and 2012. It is clearly visible that the number and size of the subsidence basins is smaller in 2012 - 31 in comparison to 51 in 2008. Data obtained from Register of Mineral Resources and Mining Areas Information [8] led by Polish Geological Institute show that in both periods hard coal extraction was carried out with similar amount of deposits, 28 in 2008 and 27 in 2012 (Fig. 5 and 6). Total extraction was 39 million tonnes in 2008 and 31 million tonnes in 2012, so lower after four years by 8 million tones. These data can indicate that decreasing of the subsidence basins number is probably related to the reduction of the hard coal exploitation.

On the other hand interferometric data which were compared, are characterized by different wavelength, ALOS - PALSAR $23.6 \mathrm{~cm}$ and TerraSAR - X $3.1 \mathrm{~cm}$. It could have some impact on the interpretation and identification of the "fringes" indicating the subsidence basins.

As an additional action simplified land use map of study area was made (based on Urban Atlas [9]), including six classes: urban, roads and railways, mineral extraction and dumps, agriculture and wetlands, forests and water bodies (Fig. 7c ). It was found that most of identified subsidence basins between Ruda Śląska and Mysłowice were localized at the forests areas. It is known that the L-band signal penetrates deeper into the vegetation cover than the X-band one. Even over vegetated areas, a remarkable part of the backscattered L-band echo arrives from the ground, rather than from the vegetation. The L-band signal is, therefore, much less sensitive to the temporal decorrelation due to changes in the vegetation cover (e.g., with the seasons).

The results of these analysis are summarized in Tab. 2 . The total area of 51 subsidence basins separated on the basis of ALOS-PALSAR is $50.03 \mathrm{~km}^{2}$ (Fig. 7a). On the other hand, 31 subsidence basins determined based on TerraSAR-X data covers an area almost two times smaller (26.20 km²) (Fig. 7b). 


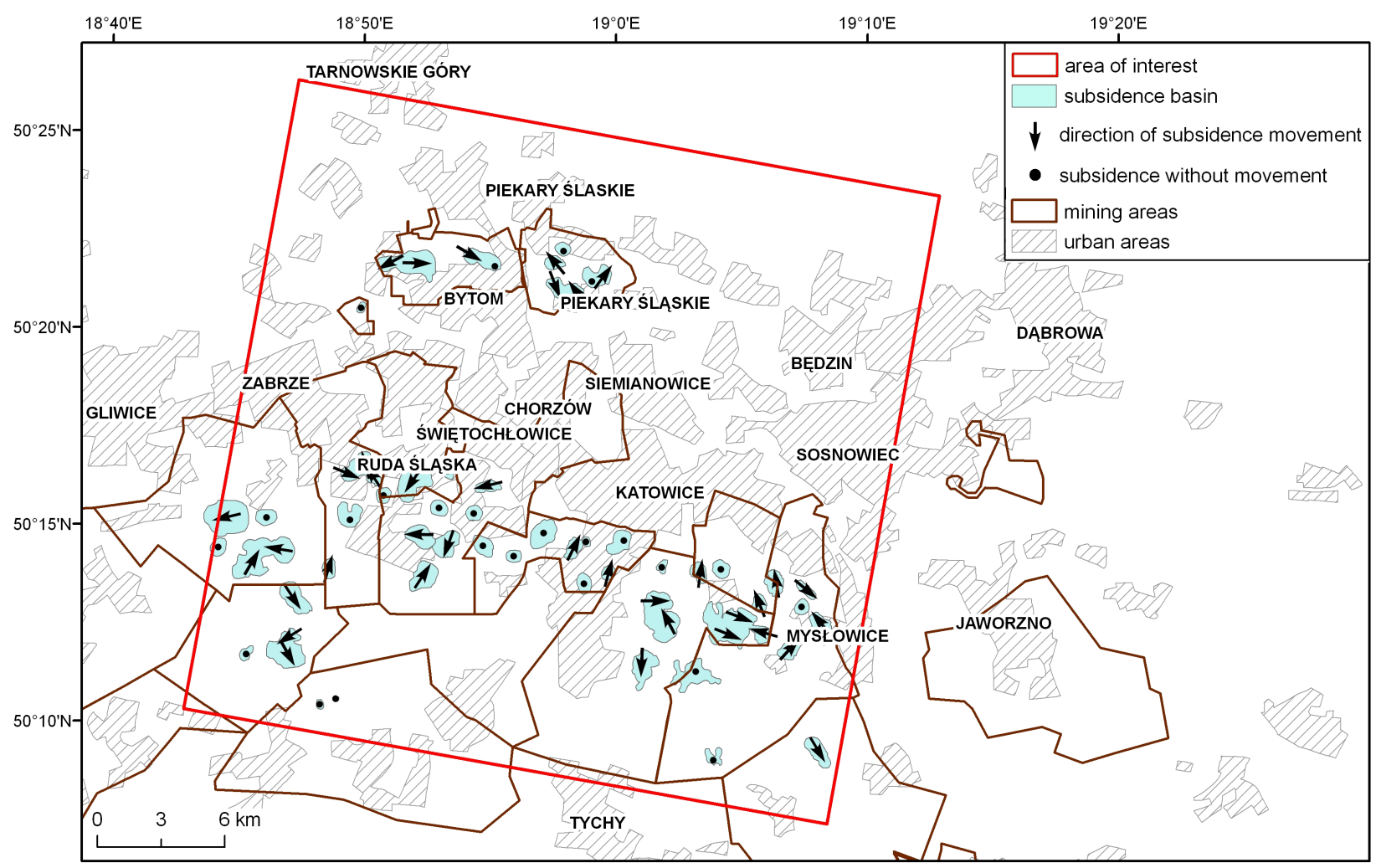

Figure 3. Subsidence movement based on ALOS-PALSAR data, period 22/02/2007 - 27/05/2008

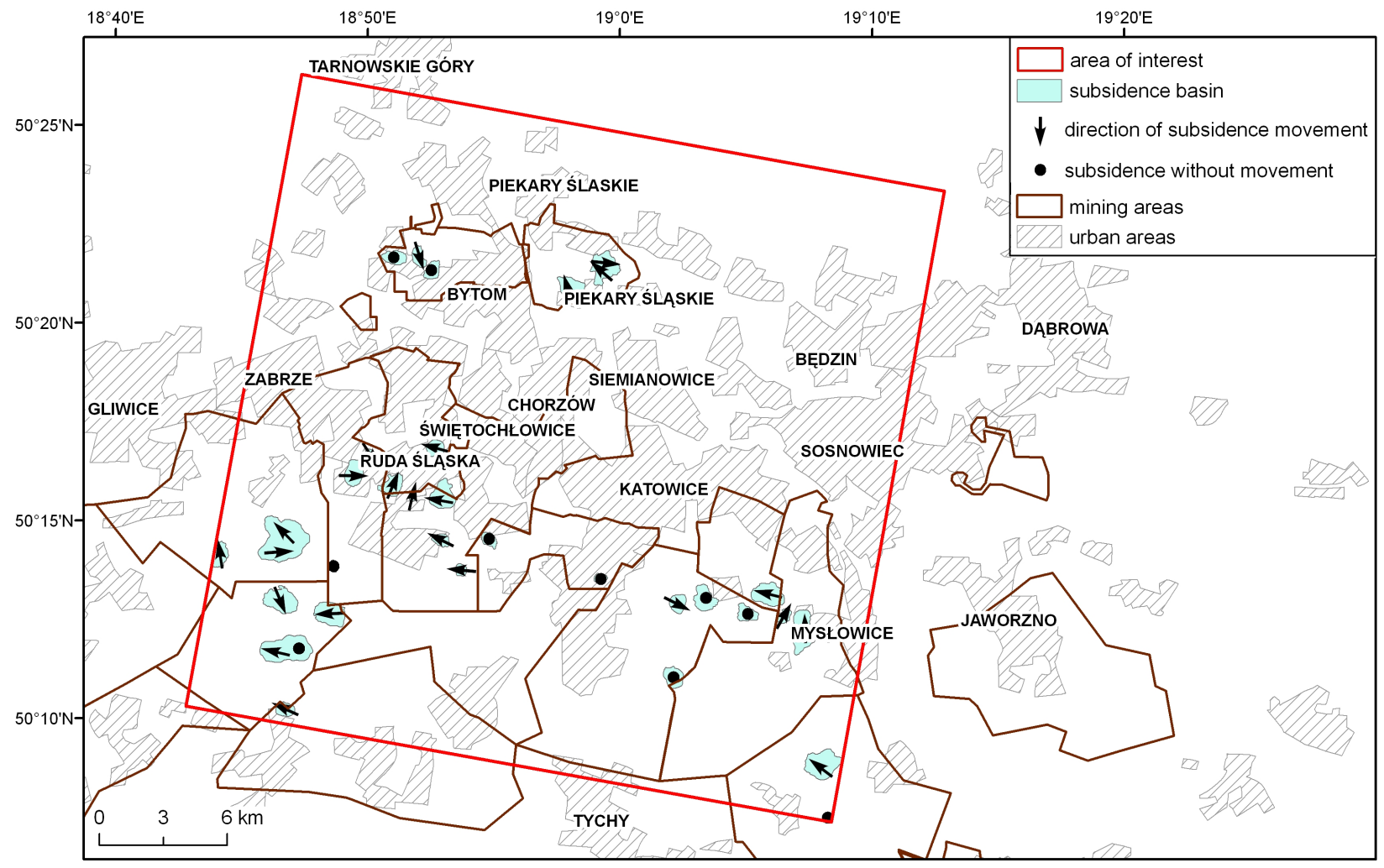

Figure 4. Subsidence movement based on TSX data, period 05/07/2011 - 21/06/2012 
The significant decrease of detection of subsidence basins for TerraSAR-X took place in forested areas. Moreover interferometric data from two different satellites were characterized by different repeated intervals: ALOS - 46 days and TerraSAR - X - 11 days. Taking this under consideration it is impossible to state firmly that lower number of identified subsidence basins in 2011 - 2012 is related only to reduction of coal exploitation. This is probably also related to the fact that shorter X-band wavelength radar beam interact mainly with upper section of trees, such brunches and trunks. Ideal solution would be comparing the data from two satellites operating in the same period.
Table 2. Land use inside the subsidence basin

\begin{tabular}{|l|r|r|}
\hline \multirow{2}{*}{ Land use } & \multicolumn{2}{c|}{ area [sq. km / (\%)] } \\
\cline { 2 - 3 } & \multicolumn{1}{c|}{ ALOS } & \multicolumn{1}{c|}{ TSX } \\
\hline urban & $11,64(23)$ & $6,34(24)$ \\
\hline roads and railways & $2,11(4)$ & $1,02(4)$ \\
\hline mineral extraction & $1,42(3)$ & $1,12(4)$ \\
\hline agriculture and wetlands & $16,07(32)$ & $12,12(47)$ \\
\hline forest & $18,35(37)$ & $5,19(20)$ \\
\hline water bodies & $0,44(1)$ & $0,23(1)$ \\
\hline
\end{tabular}

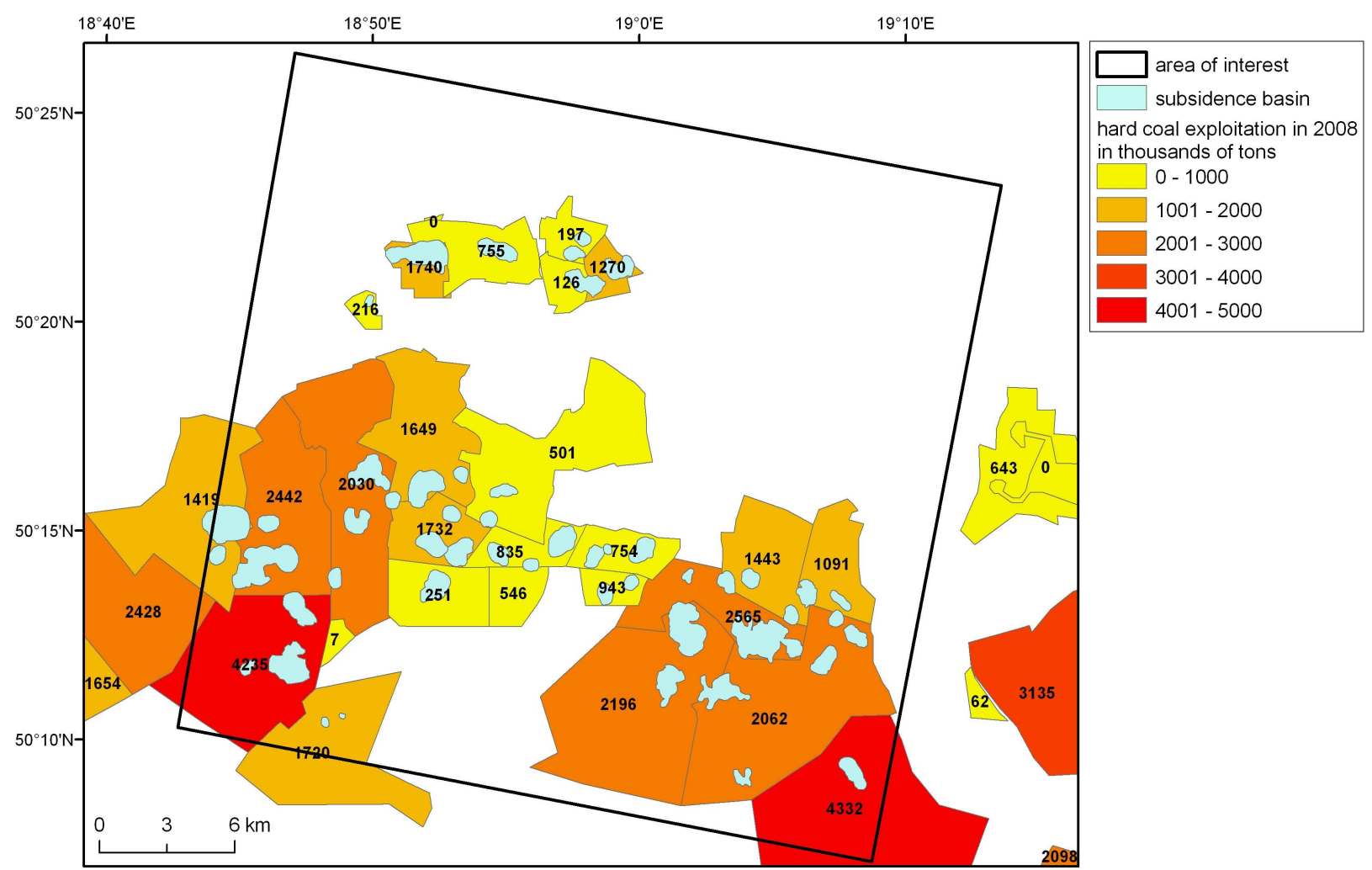

Figure 5. Exploitation of hard coal deposits in 2008 


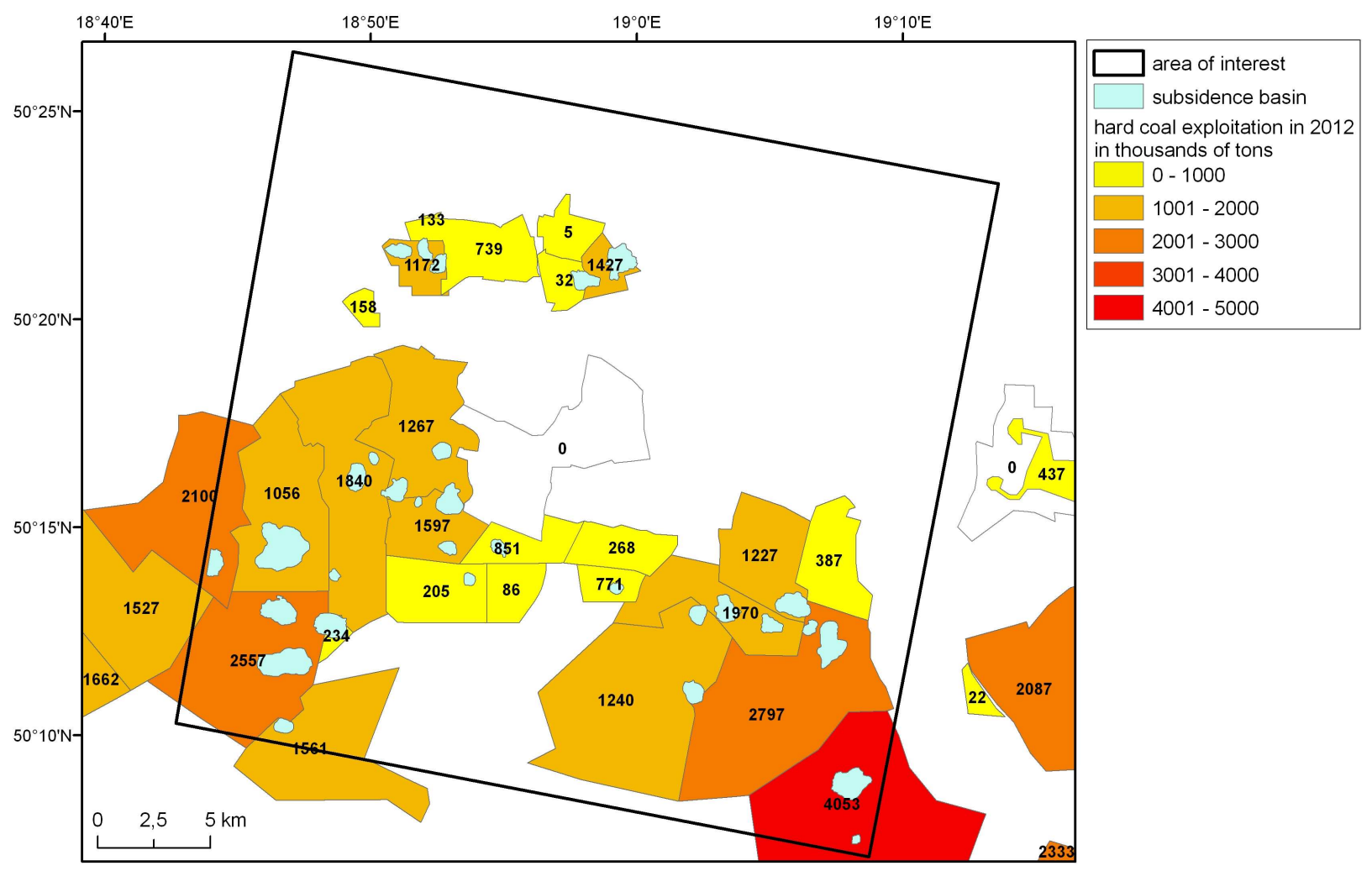

Figure 6. Exploitation of hard coal deposits in 2012
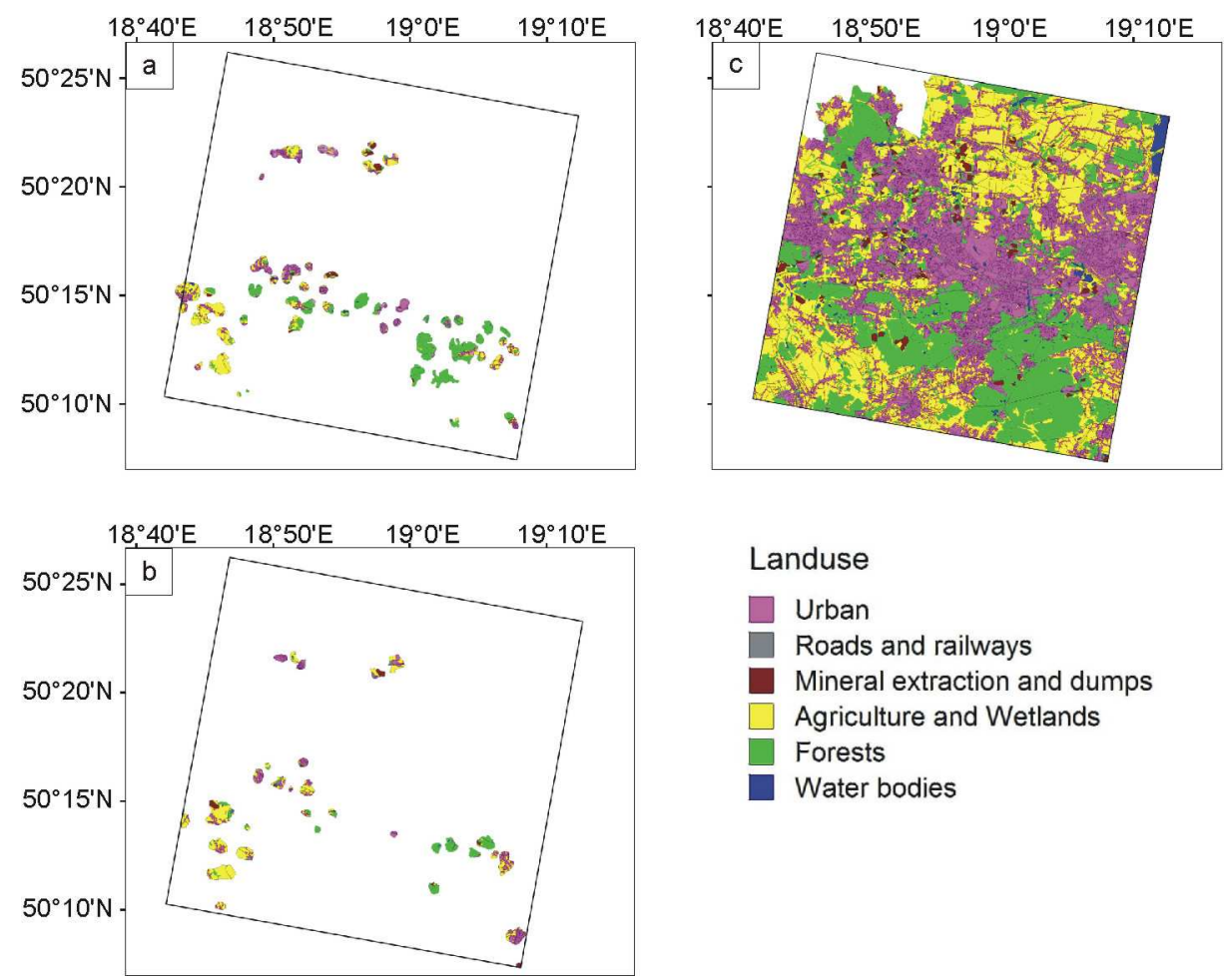

Landuse

$\square$ Urban

Roads and railways

Mineral extraction and dumps

Agriculture and Wetlands

Forests

Water bodies

Figure 7. a. Land use inside the subsidence basin bases on ALOS-PALSAR data. $b$. Land use inside the subsidence basin bases on TerraSAR-X data. c. Simplified land use map based on Urban Atlas 


\section{CONCLUSIONS}

The performed analysis showed significant changes that have emerged on the surface of the USCB between years 2007/2008 and 2011/2012. This change was probably expressed in a reduction of subsidence basins from 51 to 31 . The reduction of subsidence basins is most likely related to the limitation of the hard coal exploitation what was shown on the data of the Register of Mineral Resources and Mining Areas.

However, it should be noted that the comparative analysis covered data from two different satellite systems operating in different wavelengths (bands $\mathrm{X}$ and L), different resolutions, different repeated cycle and processed according to two different algorithms. These facts could also affect the final results of the analysis. Land use analysis indicated that the significant decrease of detection of subsidence basins for TerraSAR-X took place in forested areas. Taking above under consideration it is impossible to state firmly that lower number of identified subsidence basins in 2011 2012 is related only to reduction of coal exploitation. Ideal solution would be comparing the data from two satellites operating in the same period.

The obtained results emphasize the importance of satellite interferometry method for monitoring land surface at the mining areas and should be used for verification of the local territorial plans as well as should be taken under consideration during risks assessment related to mining activity.

\section{REFERENCES}

1. Perski, Z. (1998). Applicability of ERS-1 and ERS-2 InSAR for land subsidence monitoring in the Silesian coal mining region, Poland. International Archives of Photogrammetry and Remote Sensing 1998, 32, 555-558.

2. Spreckels V., J. Musiedlak U., Wegmüller, Strozzi T., and Wichlacz C. (2001). Detection of underground coal mining-induced surface deformation by differential InSAR data. ISPRS WG I/2, I/5, IV/7 Workshop on High resolution mapping from space, Hannover, Germany.

3. Wegmüller U., Werner Ch., Strozzi T., and Wiesmann A. (2004). Monitoring mining induced surface deformation. Geoscience and Remote Sensing Symposium, 2004. IGARSS '04. Proceedings. 2004 IEEE International (Volume 3), pp. $1933-1935$.

4. Eineder, M., Runge, H., Boerner, E., Bamler, R., Adam, N., Schättler, B., Breit H., Suchandt, S. (2003). SAR interferometry with TerraSAR-X. In Proc. of FRINGE 2003 Workshop, Frascati (pp. 1$5)$.
5. Buła, Z. Kotas, A. (1994). Atlas geologiczny Górnośląskiego Zagłębia Węglowego. Mapy strukturalne. Cz. 3. PIG, Warsaw, Poland.

6. Konopko, W. (2010). Wydobycie węgla i destrukcja górotworu w Górnośląskim Zagłębiu Węglowym. Przegląd Górniczy 2010(66), 1-10.

7. GIG. (2012) Obszary górnicze kopalń podziemnych oraz płytkie eksploatacje rud i węgla kamiennego w Górnośląskim Zagłębiu Węglowym. Mapy Ścienne, Beata Piętka, Katowice, 2012.

8. PGI-NRI. Midas service. Avaiable online: http://geoportal.pgi.gov.pl/portal/page/portal/MID ASGIS/start (accessed on 13-01-2015).

9. http://www.eea.europa.eu/data-and-maps/data/urbanatlas (accessed on 13-01-2015). 